J.F. Hardy MD, M. Boulanger MD, J.G. MAILLÉ MD, B. Paiement MD, J. Taillefer MD, P. Sahab MD, M. Delorme MD

\title{
Arterial hypertension following coronary artery surgery: Influence of the narcotic agent used for anaesthesia
}

Mcllvaine et al. reported that morphine anaesthesia $\left(1.5 \mathrm{mg} \cdot \mathrm{kg}^{-1}\right)$ was associated with a lower incidence of postoperative hypertension (3.8 per cent) following coronary artery bypass grafi surgery ( $C A B G)$, compared to 28 per cent when low dose fentanyl $\left(7.5-10 \mu \mathrm{g} \cdot \mathrm{kg}^{-1}\right)$ and halogenaied agents were used for anaesthesia. Since in this earlier study the relative dosage of the narcotics used could not be considered as equivalent we compared the incidence of postoperative hypertension in two groups of 24 patients operated for $C A B G$ : one group received

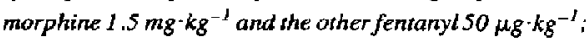
these doses are cansidered clinically equivatent. In both groups, patients breathed a mixture of nitrous oxide oxygen (3/2). All patients had normal ventricular function. There was not a single case of postoperative hypertension in the morphine group whereas seven cases occurred in the fentanyl group (29 per cent). The incidence of preaperative hypertension was similar in both groups. During the operation, before the extracorporeal circulation, supplementation of anaesthesia to

\section{Key words}

ANAESTHESIA: cardiovascular, ANALGESICS: morphine, fentanyl, complicatTons: hypertension.

From the Department of Anaesthesia, Montreal Heart Institute and the Department of Anaesthesiology, University of Montreal, Faculty of Medicine, Montreal, Quebec.

Address correspondence to: Marcel Boulanger MD, Anaesthesiology Department, Montreal Heart Institute, 5000 Belanger Street East, Montreal, Quebec, Canada HIT 1 C8. maintain cardiovascular stability was necessary wice as often in the morphite group as in the fentanyl group (40 vs 19). These results show that morphine anaesihesia prevents postoperarive hypertension in CABG; clinically equivalent doses of fentanyl do not. However, during surgery, for the period preceding the extracorporeal circulation, fentanyl seems to be preferable to morphine for the coronary patients. This work suggests that a technique combining both narcotics might be advantageous: fentanyl being used before the extracorporeal circulation and morphine during and after, to prevent the postoperative hypertension. It remains to be determined if such a combination would be effective and would not present untoward effects such as delaying recovery, prolonging intubation period and ICU stay.

The incidence of postoperative hypertension in coronary surgery has been variably reported since 1972 as between 30 and 75 per cent. ${ }^{1-4}$ In 1977 a vigilance program set up at the Montreal Heart Institute to detect the incidence of hypertension disclosed a 3.5 per cent incidence in 200 cases of coronary surgery.

Three years later, in 1980, the same vigilance programme showed a 23.7 per cent incidence. On closer examination, it was realized that the surgical technique, the cardioplegic solution, the extracorporeal circulation time (ECC), and level of hypothermia had not changed. However, the anaesthetic technique had been modified; in 1977 all patients were anaesthetized with morphine sulfate (1.5 to $2 \mathrm{mg} \cdot \mathrm{kg}^{-1}$ ) supplemented as necded with halogenated agents and occasionally with vasodilators. In 1980, only one anaesthetist was still using this 
technique, the others having replaced morphine with low dose fentanyl ( 7 to $10 \mu \mathrm{g} \cdot \mathrm{kg}^{-1}$ ) supplemented as needed by halogenated agents.

Observation of the relative incidence of hypertension according to the anaesthetic technique used showed that the anaesthetist still using morphine had one single case of hypertension in 40 patients while all the other cases were shared by the four other anaesthetists.

These findings previously reported by our groups introduced the question whether the incidence of hypertension would be the same in two groups of coronary artery bypass graft patients (CABG) anaesthetized with morphine and fentanyl at clinically equivalent dosage.

The present work addresses this question and compares the incidence of postoperative hypertension in a group of $24 \mathrm{CABG}$ patients receiving morphine $1.5 \mathrm{mg} \cdot \mathrm{kg}^{-1}$ to a similar group receiving fentanyl $50 \mu \mathrm{g} \cdot \mathrm{kg}^{-1}$. These doses are considered to be clinically, but not pharmacologically equivalent (see discussion).

\section{Methods}

Forty-eight patients (24 in each group) scheduled for CABG surgery were studied between October and December 1981. Patients with poor ventricular function (ejection fraction lower than 0.5 and/or abnormal ventriculography) and those scheduled for mixed surgery, aneurysmectomy or valvular surgery were excluded. To minimize the influence of personal preferences of collaborators, the cases were distributed as equally as possible among them. The assignment of patients to either group was randomized by drawing lots.

The following protocol was followed.

\section{(1) Preoperative visit and premedication}

The preoperative visit was carried out along the usual practice of the Montreal Heart Institute. ${ }^{6}$ As the anaesthetic techniques proposed were common practice in our centre as in many others, the Ethics Committee of our institution was satisfied with the usual consent to surgery and anaesthesia.

On awakening, $50 \mathrm{mg}$ of hydroxyzine was administered orally. At 0700 hours, morphine $0.1 \mathrm{mg}$. $\mathrm{kg}^{-1}$ (maximum $10 \mathrm{mg}$ ) and scopolamine $0.4 \mathrm{mg}$ were administered by intramuscular injection.

On the night before operation, patients received diazepam or secobarbital and their usual nitrate and beta-blocking therapy (most patients were receiving isosorbid dinitrate and propranolol).

\section{(2) Operating room monitoring}

Monitoring devices placed under local anaesthesia before induction included a radial artery cannula, internal jugular vein Swan-Ganz catheter and a CS5 EKG lead. Slow speed continuous recordings of the EKG, arterial pressure, pulmonary artery pressure and heart rate were made for all patients during the operation.

\section{(3) Induction of anaesthesia}

Patients received diazepam $0.3 \mathrm{mg} \cdot \mathrm{kg}^{-1}$ followed by the opiate drug. Morphine was injected in increments to a maximum of $1.5 \mathrm{mg} \cdot \mathrm{kg}^{-1}$ and fentanyl in drip infusion to a maximum of $50 \mu \mathrm{g}$ $\mathrm{kg}^{-1}$. The infusion rate was adjusted according to the response of the patient, as assessed by blood pressure changes. For both drugs, the entire dose was administered before stemotomy. The patients were ventilated with 100 per cent oxygen and paralyzed with pancuronium $0.1 \mathrm{mg} \cdot \mathrm{kg}^{-1}$. In some cases, the anaesthetist injected $1.5 \mathrm{mg} \cdot \mathrm{kg}^{-1}$ of lidocaine intravenously before intubation to prevent hypertension. All supplemental medications given during the operation were recorded. After intubation, the bladder was catheterized, extemal jugular vein cannulated, a naso-gastric tube passed and oesophageal and rectal temperature probes inserted.

\section{(4) Maintenance}

Patients were ventilated with 40 per cent oxygen and nitrous oxide to maintain a normal $\mathrm{PCO}_{2}$ (35 to $40 \mathrm{mmHg}$ ).

During the operation, no further opiate drug was administered and anaesthetic supplementation for maintenance consisted of halogenated agents and/or sodium nitroprusside andior nitroglycerin. The priming solution of the pump and the composition of the cardioplegic solution are shown in Appen$\operatorname{dix} \mathrm{A}$.

Following adequate heparinization ( 300 units $\mathrm{kg}^{-1}$ for an ACT $^{*}>400 \mathrm{sec}$ ), extracorporeal circulation (ECC) with non-pulsatile flow was started using a bubble oxygenator. The $\mathrm{PCO}_{2}$ and $\mathrm{PO}_{2}$, corrected for temperature, were maintained within normal limits; the haematocrit was adjusted to about 22 per

*Activated Coagulation Time. 
TABLE I Surnmary information

\begin{tabular}{|c|c|c|c|}
\hline & $\begin{array}{l}\text { Fentanyl } \\
(N: 24)\end{array}$ & $\begin{array}{l}\text { Morphine } \\
(N: 24)\end{array}$ & $P$ \\
\hline \multicolumn{4}{|l|}{ Population characteristics } \\
\hline \multirow[t]{2}{*}{$\operatorname{Sex}$} & Male 23 & Male 19 & \\
\hline & Female I & Female 5 & \\
\hline Weight & $74.3 \pm 10.5$ & $7.5 \pm 13.10$ & NS \\
\hline Surface area & $1.82 \pm 0.16$ & $1.81 \pm 0.23$ & NS \\
\hline Age & $52.3 \pm 23.5$ & $43.6 \pm 17.5$ & NS \\
\hline \multicolumn{4}{|l|}{ Preoperative medicanion } \\
\hline Coronary Vasodilators & 21 & 16 & NS \\
\hline Beta-blockers & 23 & 21 & NS \\
\hline \multicolumn{4}{|l|}{ Intraoperative periad } \\
\hline Dosage of narcotic (Mean) & $46.8 \mu \mathrm{g} \cdot \mathrm{kg}^{-1}$ & $1.6 \mathrm{mg} \cdot \mathrm{kg}^{-1}$ & \\
\hline Operation: no. of grafts & $2.66 \pm 1.16$ & $3.04 \pm 0.84$ & NS \\
\hline \multicolumn{4}{|l|}{ Cardioplegic solution } \\
\hline ml/min/clamping & 23.5 & 22.2 & NS \\
\hline Minimal temperature ${ }^{\circ} \mathrm{C}$ & 24.0 & 24.0 & \\
\hline Clamping (minutes) & $59 \pm 22.21$ & $67 \pm 20.35$ & NS \\
\hline \multicolumn{4}{|l|}{ Extracorporeal circulation } \\
\hline (minutes) & $105 \pm 34.83$ & $125 \pm 26.54$ & $p<0.05$ \\
\hline Hematocrit $\%$ & $24 \pm 4.5$ & $22.7 \pm 2.8$ & NS \\
\hline
\end{tabular}

Mean $\pm \mathrm{SD}$

cent and the body temperature lowered to $25^{\circ} \mathrm{C}$. The myocardial temperature was reduced to about $10^{\circ} \mathrm{C}$ by injecting the cold cardioplegic solution at the root of the aorta and by keeping the heart bathed in iced solutions in the pericardium.

After weaning from ECC, anaesthesia was supplemented as needed with nitrous oxide, halogenated agents and/or vasodilators. The perfusate remaining in the oxygenator was reinfused to the patient in the operating room or in the intensive care unit during the following hours.

\section{(5) Postoperative care}

Ventilation was adjusted to maintain normal blood gases. Sedation and analgesia were achieved with alternating doses of diazepam $5 \mathrm{mg} \mathrm{IV}$ and morphine $5 \mathrm{mg}$ IV. When the blood pressure remained above $160 \mathrm{mmHg}$ systolic and/or $100 \mathrm{mmHg}$ diastolic despite clinically adequate sedation and analgesia (quiet or asleep, tolerating respirator and non-shivering), sodium nitroprusside was administered to control hypertension. Postoperative hypertension was defined as a systolic blood pressure greater than $160 \mathrm{mmHg}$ and/or a diastolic pressure greater than $100 \mathrm{mmHg}$. These criteria were adopted to allow comparison with other publications on the subject. ${ }^{1,5}$
The measurement of the arterial blood pressure was performed as described previously. ${ }^{5}$

Several patients received intravenous nitroglycerin in the intensive care unit for problems related to myocardial ischaemia and not for hypertensive episodes.

\section{Results}

Table I describes the population studied: there were more females (21 per cent) in the morphine group than in the fentanyl group (four per cent). Patients in the morphine group were somewhat younger.

Surgery was uneventful in all cases; the morphine group received more grafts during a longer ECC period than the fentanyl group.

No patients in the morphine group developed postoperative hypertension whereas nine in the fentanyl group (37 per cent) experienced hypertension necessitating nitroprusside therapy, $p=0.0008$ (Table I). Note that the same incidence of preoperative hypertension is observed in both groups (25 per cent).

When preoperative hypertensives are excluded from both groups, the incidence of postoperative hypertension in the fentanyl group is 33 per cent ( $6 / 18$ patients; $p=0.0095$ when compared with the morphine group). No preoperative hypertensive 
TABLE II Incidence of postoperative hypertension

\begin{tabular}{llll}
\hline & Fentangl & Morphine & \\
\hline $\begin{array}{l}\text { (1) Total population } \\
\text { (2) Excluding preoperative }\end{array}$ & $9 / 24(37 \%)$ & $0 / 24$ & $\mathrm{p}=0.0008$ \\
$\begin{array}{l}\text { hypertensives } \\
\text { (3) Excluding patients who } \\
\text { received IV propranolol }\end{array}$ & $6 / 18(33 \%)$ & $0 / 18$ & $\mathrm{p}=0.0095$ \\
\hline
\end{tabular}

became hypertensive in the postoperative period in the morphine group whereas 50 per cent did so in the fentanyl group, $p=0.09$

Furthermore, if all patients who received IV propranolol during the operation are excluded, the incidence of postoperative hypertension is 46 per cent in the fentanyl group, $p=0.03$ when compared to the morphine group.

The anaesthetic supplements necessary during maintenance of anaesthesia are presented in Table III. The pharmacological interventions deemed necessary were twice as numerous before $\mathrm{ECC}$ in the morphine group.

Table IV presents the postoperative use of vasodilators. As mentioned previously in our institution nitroglycerin is mainly used for treating or preventing myocardial ischaemia whereas sodium nitroprusside is used to treat hypertensive episodes. The doses presented for nitroglycerin are the maximum dose used at one time or another in the course of its administration. The number of patients receiving nitroglycerin and the maximal doses used did not differ significantly in both groups.

\section{Discussion}

The pathophysiology of the postoperative hypertension is unknown; different mechanisms are postulated regarding the protective action of morphine: prolonged analgesia and/or sedation, persisting venodilation in the postoperative period, action on myocardial receptors.

The results of this prospective study confirm the hypothesis previously presented by McIlvaine et $\mathrm{al}^{5}$ that morphine anaesthesia at doses of $1.5 \mathrm{mg}$. $\mathrm{kg}^{-1}$ reduces the incidence of postoperative hypertension in CABG patients, and presents evidence that fentanyl in moderately high dose $\left(50 \mu \mathrm{g} \cdot \mathrm{kg}^{-1}\right)$ does not offer such protection against post $\mathrm{CABG}$ hypertension.

The presence of preoperative hypertension does not appear to be a predisposing factor for the
TABLE II Frequency of supplementation of anaesthesia*

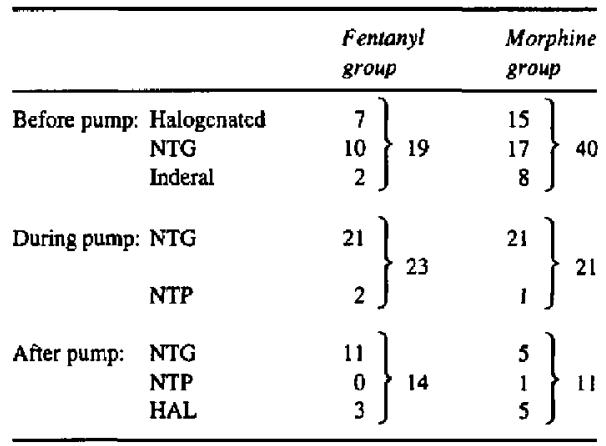

*NoTE: The figures indicate the number of pharmacological interventions; some patients having more than one.

development of postoperative hypertension (Table II). The incidence of preoperative hypertension was similar in both groups, yet there is a statistically significant difference in the postoperative incidence, Excluding preoperative hypertensives from both groups preserves the significant postoperative difference.

The same remark applies to the patients who received IV propranolol. If these patients are excluded, the difference of incidence remains significant at a level of $\mathrm{p}=0.03$.

Several patients in both groups received IV nitroglycerin in the postoperative period, which could have prevented hypertension from developing. However, the doses used were below the level at which nitroglycerin has any arterial dilating effect. ${ }^{26}$ Moreover, it was administered through polyvinyl tubing which was likely to further reduce the amount of drug reaching the patient.

It is important to note that we have used doses of narcotics which we consider clinically equivalent. Basically, we have used nitrous oxide/relaxant anaesthesia supplemented with high dose narcotics. As for the actual analgesic potency of these two 
TABLE IV Use of vasodilators in postoperative period

\begin{tabular}{lrll}
\hline & & $\begin{array}{l}\text { Moximat systolic } \\
\text { pressure observed } \\
\text { before treatment }\end{array}$ \\
\hline Morphine group & $7 / 14$ & $\begin{array}{l}\text { Nitroglycerin }\left(0.416 \pm 0.388 \mu \mathrm{g}^{-1} \cdot \mathrm{min}^{-1}\right) \\
17 / 24\end{array}$ & $\begin{array}{l}\text { No vasodilator } \\
\text { Fentanyl group }\end{array}$ \\
& $9 / 24$ & $\begin{array}{l}\text { Sodium nitroprusside } \\
\text { Nitroglycerin }\left(0.39 \pm 0.33 \mu \mathrm{mg} \cdot \mathrm{kg}^{-1} \cdot \mathrm{min}^{-1 *}\right)\end{array}$ & $155 \mathrm{mmHg}$ \\
& $6 / 24$ & No vasodilator & $216 \mathrm{mmHg}$ \\
\hline
\end{tabular}

* Maximum dose used at any time in the course of administration.

anaesthetic managements, we could not find any published material that could allow us to make valuable comparison. To our knowledge, there is no comparable MAC BAR value for morphine and fentanyl. ${ }^{10}$ On the other hand, the analgesic potency of both drugs is reported to have such a wide range that anyone could have this choice. ${ }^{7,9-18}$ Because of these shortcomings, we have not tried to achieve equianalgesic management (which is impossible to prove with the available information) but rather, we have elected to compare doses that are commonly used in the clinical setting in North America. Thus we decided to use doses that appeared to us clinically equivalent in the light of published reports.

The use of morphine in cardiac surgery goes back to the late $1960 \mathrm{~s}$ when Lowenstein et al. reported its use in patients with severe aortic valvular diseases. ${ }^{13-25}$ The cardiovascular stability obtained with morphine $1 \mathrm{mg} \cdot \mathrm{kg}^{-1}$ has popularized this technique. The other advantages recognized with morphine as the main anaesthetic agent were: absence of catecholamine sensitization of the myocardium as compared to halothane, easy transition to postoperative ventilatory support and prolonged postoperative sedation and analgesia. ${ }^{14,15}$

This prolonged sedation and analgesia is, in our mind, desirable: early extubation has not been shown to have advantages, ${ }^{15}$ and the pain of the early postoperative period is intense and justifies heavy analgesia. This point is supported by the personal experience of an anaesthesiologist. ${ }^{16}$ However, morphine is not without undesirable features which include: hypotension, ${ }^{12-14}$ hypertension, ${ }^{17}$ cardiovascular depression when combined with nitrous oxide, ${ }^{24}$ increase in circulatory catecholamines, ${ }^{25}$ increase in fluid requirements, ${ }^{21}$ risk of awareness during anaesthesia, ${ }^{12}$ postoperative psychosis and medullary stimulation with doses of 7 to $8 \mathrm{mg} \cdot \mathrm{kg}^{-1}{ }^{14}$

In the morphine group tachycardia and increased arterial pressure following intubation and sternal spreading were commonly observed in this study as indicated by the more frequent supplementation of anaesthesia with halogenated agents, nitroglycerin and/or beta-blockers. This increased number of pharmacological interventions in the pre-bypass period in patients annesthetized with morphine as opposed to fentanyl could lead one to conclude that in this period the drugs are not equally analgesic but it also could be related to the personal biases of the participating anaesthesiologists, which were left unopposed for lack of rigid standardization of the anaesthetic technique. However, it is unlikely that these interventions would have any influence on postoperative hypertension because only short acting or volatile agents were used; as for the propranolol administered in the pre-bypass period, the doses used were so small and were administered so many hours before the postoperative observation period, that it is unlikely to have any effect on the incidence of postoperative hypertension. Indeed, when patients who received IV propranolol were excluded, the incidence of hypertension remained significant at the 0.03 level.

In the quest for the ideal agent, fentanyl has been used at very high doses, ${ }^{9,18}$ The intraoperative haemodynamic stability appears superior to that obtained with morphine, possibly due to better analgesia. ${ }^{11}$ Fentanyl does not produce venodilation and the fluid requirements are not increased; ${ }^{7}$ unconsciousness, however, is not always guaranteed ${ }^{8}$ Indeed, the plasma level of fentanyl falls rapidly below the level where unconsciousness 
occurs even with doses greater than $75 \mu \mathrm{g} \cdot \mathrm{kg}^{-1}, 18$ The use of a loading dose followed by a constant maintenance drip is more rational and possibly safer for the patient. ${ }^{23}$

Previous work on postoperative hypertension and this study suggest that a technique combining morphine and fentanyl could possibly offer the best of two worlds: cardiovascular stability before the start of ECC and prevention of postoperative hypertension. The ideal doses have not been determined. When well tolerated, supplementation with nitrous oxide and/or halogenated agents can further reduce the narcotic doses and insure unconsciousness.

The ideal dose and timing of morphine administration to prevent postoperative hypertension remains to be determined. Previous work ${ }^{5}$ has shown a tendency (not statistically significant, however) to reduce the incidence of postoperative hypertension from 28 to 18.7 per cent when morphine was administered following ECC. The ideal moment for administering morphine would appear to be immediately before ECC, thus providing analgesia during $\mathrm{ECC}$ and hopefully preventing postoperative hypirtension. However, it remains to be determined whether this combination will be effective in preventing postoperative hypertension, without delaying awakening; the risk of prolonging the intubation period and the ICU stay needs to be evaluated.

The ideal anaesthetic agent does not yet exist and we suggest a combination of both opiates in the overall perioperative management of $\mathrm{CABG}$ patients. This is currently being tested in our department.

\section{References}

1 Estafanous FG, Tarazi RC, Viljoen JF, El Tawil $M Y$. Systemic hypertension following myocardial revascularization. Am Heart J 1973; 85: 732-8.

2 Pratilas V, Pratila MG, Vlachakis ND, Owithz $S$, Dimich I. Sympathetic neryous system tonicity and post-coronary artery bypass hypertension. Acta Anaesthesiol Scand 1980; 24: 69

3 Fouad FM, Estafanous $F G$, Bravo EL, lyer $K A$, Maydak JH, Tarazi RC. Possible role of cardioaortic reflexes in postcoronary bypass hypertension. Am J Cardiol $1979 ; 44: 866-72$.

4 Hoar PF, Hickey RF, Ullyot DJ. Systemic hypertension following myocardial revascularization. A method of treatment using epidural anesthesia. J Thorac Cardiovasc Surg 1976; 71: 859-64.

5 Mcllvaine W, Boulanger M, Maillé JG, Paiement $B$, Taillefer J, Sahab $P$. Hypertension following coronary artery bypass graft. Can Anaesth Soc J 1982; 29: 212-7.

6 Paiement B, Maille JG, Boulanger $M$, et al. La visite pré-opératoire en chirurgie cardiovasculaire. Can Anaesth Soc J 1980; 27: 584-93.

7 Stanley $T H$, Webster RL. Anesthetic requirements and cardiovascular effects of fentanyl- $\mathrm{O}_{2}$ and fentanyldiazepam oxygen anesthesia in man. Anesth Analg 1978; 57: 411-6.

8 Mummaneni N, Rao TLK, Monsoya A. Awareness and recall with high dose fentanyl-oxygen anaesthesia. Anesth Analg 1980; 59; 948-9.

9 Sebel PS. Fentanyl anaesthesia in cardiac surgery. Academic Thesis, Academic Hospital, University of Amsterdam. Publisher Janssen Pharmaceutica, 1981.

10 Roizen $M F$, Horrigan RW, Frazer BM. Anesthetic doses blocking adrenergic (stress) and cardiovascular tesponses to incision - MAC BAR. Anesthesiology 1981; 54: 390-8.

11 Stanley $T H$, Berman L, Green O, Robertson D. Plasma catecholamine and cortisol responses to fentanyl-oxygen anesthesia for coronary-artery operations. Anesthesiology 1980; 53: 250-3.

12 Lowenstein E. Morphine anesthesia: A perspective (editorial). Anesthesiology 1971; 35: 563-5.

13 Lowenstein E, Hallowell P, Levine FH, Dagget WM, Austen WG, Laver BM. Cardiovascular response to large doses of intravenous morphine in man. $\mathrm{N}$ Engl J Med 1969; 281: 1389-93.

14 Arens $J F$, Benbow BP, Ochsner $J L$, Theard R. Morphine anesthesia for aortocoronary bypass procedures. Anesth Analg 1972; 51: 901-9.

15 Quasha AL, Loeber N, Feeley TW, Utlyot DJ, Roizen $M F$. Postoperative respiratory care: a controlled trial of early and late extubation following coronary artery bypass grafting. Anesthesiology 1980; 52: 135-41.

16 Goldsmith E. My hear stood still: the personal case history of an anaesthetist. Anaesthesia 1981; 36: 1142 .

17 Kistner JR, Miller ED, Lake CL, Ross WT. Indices of myocardial oxygenation during coronary-artery revascularization in man with morphine versus halothane anesthesia. Anesthesiology 1979; 50: 324-30.

18 Lunn JK, Stanley TH, Eisele J, Webster L, Woodward $A$. High dose fentanyl anesthesia for coronary 
artery surgery: plasma fentanyl concentrations and influence of nitrous oxide on cardiovascular responses. Anesth Analg 1979; 58: 390-5.

19 Benrett GM. Stanley TH. Human cardiovascular responses to endotracheal intubation during morphine$\mathrm{N}_{2} \mathrm{O}$ and fentanyl- $\mathrm{N}_{2} \mathrm{O}$ anesthesia. Anesthesiology 1980; 52: 520-2.

20 Stanley TH, Gray NH, Isern-Amaral JH, Patton $C$. Comparison of blood requirements during morphine and halothane anesthesia for open heart surgery. Anesthesiology, 1974; 41: 34-8.

21 Stanley TH, Gray NH, Stanford W, Armstrong $R$. The effects of high dose morphine on fluid requirements in open heart operations. Anesthesiology 1973; 38: 536-41.

22 Hall GH, Young C, Holdcraft A. Substrate mobilization during surgery: A comparison between halothane and fentanyl anesthesia. Anaesthesia 1978; 33: 924.

23 Sprigge JJ, Wynands JE. Whalley DG et al. Haemodynamic responses and serum fentanyl levels during fentanyl infusion anaesthesia (Abstract). Can Anaesth Soc J 1982; 29: 495.

24 McDermot RW, Stanley TH. The cardiovaseular effects of low concentrations of nitrous oxide during morphine anesthesia. Anesthesiology 1974; 41 : 89-91.

25 Hasbrouk JD. Morphine anesthesia for open heart surgery. Ann Thorac Surg 1970; 10: 364-9.

26 Gerson $J$, Allan FB, Seltzer JL, Parker FB Jr, Markowitz $A H$. Arterial and venous dilation by nitroprusside and nitroglycerin - Is there a difference? Anesth Analg 1982; 61: 256-60.

\section{Résumé}

Les travaux de Mclivaine et collaborateurs ont montré que l'anesthésie d base de Morphine $1.5 \mathrm{mg} \mathrm{kg}^{-1}$ semble prévenir l'hypertension paroxystique post-opératoire dans la chirurgie du pontage aorio-coronarien. L'incidence observée a été de 3.8 pour cent versus 28 pour cent lorsque l'anesthessie était faite de Fentanyl d petites doses complétée par des agents halogénés.

Ce travail campare l'incidence de l'hypertension post-opératoire chez un groupe de 24 malades recevant Morphine $1.5 \mathrm{mg} \cdot \mathrm{kg}^{-1}$ d un autre groupe de 24 malades recevant Fentanyl $50 \mu \mathrm{g} \cdot \mathrm{kg}^{-1}$ (ces doses etant considerées comme cliniquement comparables). Tous les patients recevaient d'autre part protoxyde d'azoteaxygène (3/2) et avaient une fonction ventriculaire normale. La prémédication ex la technique d'induction étaient identiques dans les deux groupes.

Résultats: On a observé aucun cas d" hypertension chez les malades recevant de la Morphine, contre 9/24 cas $\$ 37$ pour cent) dans les malades du groupe Fentanyl. Notez que l'incidence d'hypertension pré-opératoire était la méme dans les desux groupes.

Durant l' intervention avant la circulation extra-corporelle, on a da intervenir pharmacologiquement (agents halogénés, Nirroglycérine, Nitroprussiate, bêta-bloquants) deux fois plus fréquemment dans le groupe Morphine que dans le groupe Fentanyl.

Conclusion: Ces résultats montrent que l'anesthésie à la Morphine possède un effet préventif de l'hypertension post-opératoire par rapport à des doses communémem employées de Fentanyl. Cependant, durant la chirurgie, pour la période précédant la C.E.C., le Fentanyl apparât supérieur à la Morphine pour l'anesthésie du malade coronarien.

Ces travaux suggèrent que la combinaison des deux morphiniques, Fentanyl avant la circulation extra-corporelle et Morphine administrée pendant et après la C.E.C., serait bénéfique en assurant la stabitité cardiovasculaire pendant l' intervention et la prévention d'hypertension paroxystique post-opératoire. Il reste d̀ savoir si cette combinaison sera efficace et n'aura pas d'effers indésirables tels que prolongation du temps de réveil et de r' intubation post-opératoire, de même qu'allongement du séjour aux soins intensifs.

\section{Appendix A}

Cardioplegic solution composition

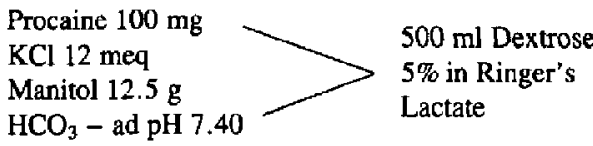

Oxygenator prime

$1 / 3 \mathrm{DW} 5 \%$

2/3 Ringer's Lactate 